\title{
Protection of Malaysia Small Farmers Under the Plant Variety Law: an Appraisal
}

\author{
Murshamshul Kamariah Musa \\ Universiti Sultan Zainal Abidin \\ Terengganu, Malaysia
}

\begin{abstract}
Plant genetic resources (PGR) is one the most important genetic resources in the agricultural field. PGR play a vital role towards the betterment of global nutrition and health. This article discusses Regarding the appraisal of Protection of Malaysia Small Famers Under the Plant Variety Law. The Revolution, Farmers Right, the Issues, and observation becomes an important discussion of the results and discussion of article.
\end{abstract}

Keywords - Small Famers; Plant Variety Law; Protection

\section{INTRODUCTION}

Plant genetic resources (PGR) is one the most important genetic resources in the agricultural field. PGR play a vital role towards the betterment of global nutrition and health. As the main source of genetic material for development of food crops and medicinal plants, PGR value in the world's economy is incalculable[1]. It is the most essential category of biological resources because it provides foundation for all food production and the key to feeding unprecedented number of people in times of climate and environmental change. Various types of PGR are developed, enhanced and conserved by farmers globally, rich and poor, and these particular communities continue to be the stewards of PGR through their own methods of selection, refining, maintaining, sharing and trading these particular genetic resources throughout their farming activities[2].

Plant genetic resource for food and agriculture (PGRFA) is another term for food crop plants and is an important class of PGR which are essentially man-made. This particular group of PGR is highly valued in plant breeding as it assists in developing new and better varieties of crops[3]. The diversity of genetic materials contained in PGRFA either from traditional farmers' grown varieties, modern breeds of crops or wild relatives of these PGRFA, constitute an important component of agro biodiversity[4]. Through knowledge and expertise passed on from one generation to another, farmers have contributed to the creation, conservation, exchange and knowledge of genetic and species diversity of PGRFA. Through their practises of seed selections for re-planting purposes, farmers have built up genetic diversity of crops with increased quality in terms of palatability and storage quality. Seeds are chosen based on specific characteristics deemed appropriate by farmers for their farming environment, with high economic value, displaying agronomic stability and tolerance to disease and

\author{
Zuhairah Ariff Abd Ghadas \\ Universiti Sultan Zainal Abidin \\ Terengganu, Malaysia \\ zuhairahariff@unisza.edu.my
}

pests. These seeds are acquired either from the harvest of their own fields or through sale or exchange with neighbouring farming communities[5].

Farmers' efforts at maintaining genetic diversity of PGRFA, particularly of the major staple crops of subsistence farmers, have helped in food security by offering greater defences against vulnerability to diseases, pests and environmental changes as well as enhancing harvest security[6]. To ensure food security for their households the majority of subsistence and resource-poor farmers in developing countries continue their reliance on the traditional practices of saving, exchanging and selling the seeds from their own harvest. Farmers are able to gain access to different genetic varieties of crops through this informal seed system, allowing them to select desired traits and improve their traditional crop varieties to better suit the local environment. The informal communal seed system, which values agricultural biodiversity created and preserved such diversity to be in tandem with local environments[7].

\section{RESULTS AND DISCUSSION}

\section{A. Revolution}

The revolution in genetics have changed plant breeding into a more complex, scientific process involving a greater degree of strategic manipulations. This evolutionary process of agriculture involving plant genetic resources has directly affected the farming community. The process resembles modes of industrial innovations and production. The breeding of new varieties of plants has shifted from farmers' field to scientists' laboratories[8]. The expansion of intellectual property rights (henceforth referred as IPRs) particularly plant varieties rights and patents into PGR, has created controversies about these farmers-centred practices. The private and individual nature of the IPRs is at odds with the traditional farming practices which are deeply rooted in communal good. The farmers may be considered as committing criminal acts of piracy when they continue with their millennium-old practices of saving, selecting, selling and exchanging seeds from their own field with others[9].

Oguamanam (2006) stresses that these traditional agricultural practices combined with modern day agricultural biotechnology are two primary approaches to tackle food security concerns. The farmers' practises boost genetic diversity of PGRFA ensuring continuous supply of 
raw materials for modern plant breeding which make full use of the most recent biotechnology techniques to create new varieties of crop plants for agricultural uses. Both methods are mutually beneficial and contribute to global food production. He also points out that despite the mutual beneficial relationship between traditional farming practises and modern agricultural biotechnology, issues of reward and protection between the two parties remains contentious from both a legal and policy perspective. He further argues that IPR, in the form of plant breeders' rights (hereinafter referred as PBR) and patents, which are used as mechanism for reward and protection of knowledge, is unable to provide the proper balance of rights and responsibilities between the two parties. He concludes that supporting legal framework which undermines the role of traditional farmers and their agricultural practises, in favour of modern agrobiotech practitioners, may hamper efforts of food security and sustainable agriculture as it would result in farmers depending upon corporate seed producers and monopolies of the biotechnology proprietors[10].

Plant variety protection (PVP) or also known as plant breeders' rights (PBR) is a form of intellectual property rights which grants exclusive rights to breeders of new varieties of plants to exploit their varieties. This particular right enables the holder of such right to restraint others from reproducing a new plant variety which has been protected under it. It has been described as an independent sui generis form of protection specifically tailored for the purpose of protecting new plant varieties[11]. Similar to other IPRs, it grants the holder of a plant variety right an exclusiveness of ownership subject to similar limitations which are quite common to other IPRs. The exclusive rights granted to breeders are to ensure the breeders of their opportunity to recoup the expenses of their research into a new or improved plant variety. It was argued that the exclusive rights granted to the breeders should be balanced with a society's legitimate rights - the rights of its farmers and agricultural communities, to be recognised in any plant variety protection legislation. The opening to do so, present itself through the concept of Farmers' Rights[12].

The importance of PGRFA's diversity and farmers' contributions towards agricultural diversity and food security is recognised by the Food and Agriculture Organization of the United Nations[13] (henceforth referred as FAO). The International Treaty on Plant Genetic Resources for Food and Agriculture (henceforth referred as FAO Treaty[14]) acknowledges[15] the enormous role of PGRFA in achieving the goals of Rome Declaration on World Food Security[16]. The FAO Treaty which focuses exclusively[17] on PGRFA promotes conservation and the sustainable use of PGRFA to ensure genetic diversity and food security. In order to achieve these aims, the FAO Treaty proposes implementation mechanisms in the form of Farmers' Rights concept, a multilateral system of benefit sharing and a funding strategy[18].

The role and contribution of farmers globally towards the conservation and development of PGRFA diversity, is affirmed in Paragraph 7 of the Preamble to FAO Treaty which also introduces the concept of Farmers' Rights.

Affirming that the past, present and future contributions of farmers in all regions of the world, particularly those in centres of origin and diversity, in conserving, improving and making available these resources, is the basis of Farmers' Rights.

Such affirmation is again confirmed in Article 9.1 of the FAO Treaty[19], emphasising the importance of PGRFA as a source for food and agricultural production globally and the role played by farmers in conservation and development of PGRFA.

\section{B. Farmers' Rights}

Farmers' Right is a concept which seeks to recognise the contributions of traditional farmers, particularly in the developing world towards the preservation, improvement and conservation of plant genetic resources in the agricultural field. This concept called for a recognition and reward to farmers for their effort in conservation of plant genetic diversity and protection of farmers' traditional farming and seed-saving practises from the ambit of breeders' exclusive rights. These rewards can either be monetary and non-monetary through benefit-sharing mechanisms or by enabling farmers to claim exclusive rights over plant varieties which they cultivate traditionally[20]. Four core principles of Farmers Rights concept has been articulated under Article 9 of the FAO Treaty to be carried out by national governments as a measure towards strengthening the rights of farmers. The four core principles namely right to seeds, right to traditional knowledge, right to equitable benefit sharing and right to participate in decision making should be given legal status either by adopting is as part of a legislation or policies benefiting the farming communities particularly for small subsistence farmers in developing countries such as Malaysia. The undeniable link between the pivotal which farmers particularly subsistence farmers play in ensuring continuity of food production and security has never been denies. Thus, there is an urgent need for national governments particularly from developing countries of which Malaysia is one of them to pay greater attention to these farmers.

Under the FAO Resolution 5/89, the international community was vested and entrusted, to support farmers for their continuous contributions to the conservation and sustainable use of PGRFA by providing funds and assistance to these farmers and ensuring full benefit-sharing from commercial uses of any these resources[21]. Despite this appeal to the international community, responsibility for implementing the Farmers' Rights concept, as officially recognised by the FAO Treaty[22], rests upon national governments. The biggest challenge at present is translating Farmers' Rights into practical realisation due its broad definition under the FAO Treaty, as it has proven to be quite difficult to enact despite being widely discussed at 
international fora. Suggestions of measures for the protection and promotion of rights of farmers have been made in the FAO Treaty, nonetheless they are not legally binding, leaving governments with the freedom to choose the most appropriates measures they deem fit and appropriate to suit their needs and priorities. Being voluntary measures which can be subjected to a country's national legislation, the furtherance of these measures namely the rights to protection of traditional knowledge, benefit sharing and participation in decision-making processes are dependent on the political will within the governments and demands from civil society organisations and interested groups[23].

\section{The Issues}

In order to ensure the continuing and security of food production and crop genetic diversity, there is a need to address the ability of farmers to continue their farming practices of seed saving, exchange and to have autonomy over their own seeds. The possibility of doing arises through the implementation and/or strengthening of Farmers' Rights concept by each individual country. Farmers' traditional seed saving practises have been increasingly delegitimised due to the enlargement of IP rights into agriculture. Borowiak views the Farmers' Rights concept as a 'strategy of resistance' against the perceived inequities of IPR regimes for PGRFA. He postulates that the concept should be recognised as a unique form of right - different from PBR to avoid the possibility of the concept from succumbing to the same fallacies and inequities which have triggered it in the first place. The Farmers' Rights concept can provide a platform whereby farming communities can demand and seek better recognition for their contributions, together with increased autonomy over their seeds and traditional agricultural practices. This Farmers' Rights concept is viewed as better suited than the conventional IPR to encourage innovations in farming communities and for registering innovations which are communally owned knowledge[24].

The small farming communities who plays a vital role in food security as the conserver and stewards of plant genetic diversity especially PGRFA, should be recognised and rewarded for their continuous efforts. The support and recognition through Farmers' Rights does not mean only monetary gains should be given to them, but also other kind of sharing such as support in conservation effort and facilitating access to better seed varieties and cooperation with small breeders. Such efforts are crucial in providing an incentive and development of PGRFA, which constitute the basis of food and agriculture production throughout the world.

Though there is a strong need for appropriate legal framework to tackle imbalances in the exchange and use of genetic resources, this thesis proposes to tackle this broad issue by focusing on the effects of both elements (biotechnological developments and strengthening of IPRs) on agricultural practises of farming communities with particular emphasis on small-holder farmers rather than industrial farmers.

Although a framework is already in place for the realisation of the Farmers' Rights as perceived under Article 9 of the FAO Treaty, it has not created a deep impact at international level. Regardless of the slow process at the global level, individual states should play a more active role towards the realisation of Farmers' Rights especially in the developing countries to ensure the continuous livelihood of the large population of rural farming communities in those regions. Instead of competing or trying to be IPR-like, Farmers' Rights should reflect the particular needs and address the concerns of each particular country as echoed throughout the FAO Treaty. Thus it is essential to guarantee that the small resource farmers are not left out for equity reasons by creating policies which recognises their essential role in food production. These policies may include the empowerment of farmers by including the four core rights as enumerated under Article 9 of the FAO Treaty in Malaysian legislations namely the rights of farmers to their saved seed, right to traditional knowledge, their right to equitable benefit-sharing and their right to participate in decision making processes. Small farmers who are the first link to conservation of crop diversity and continuous food production may have a bigger say through this concept. The advocates for empowerment of small farmers in Malaysia stress more on the small farmers' economic improvement[25] but leave out their legal empowerment which can be argued for under the Farmers' Rights framework.

Malaysia has acceded to the International Treaty on Plant Genetic Resources for Food and Agriculture (FAO Treaty) on 5 May 2003 as part of its international commitments[26]. As explained above, the Treaty recognises the contributions of farmers to the development and conservation of plant genetic resources for food crops and agriculture through a concept known as Farmers' Rights[27]. Malaysia is also a member of the World Trade Organizations (WTO) which regulates international trade between governments. In compliance with the requirement of Article 27.3(b) of Agreement on Trade-Related Aspects of Intellectual Property Rights (TRIPS) which is a trade instrument under the auspices of WTO, Malaysia has enacted the Protection of New Plant Varieties Act of 2004 which grants exclusive intellectual property rights, the plant variety protection (PVP), to plant breeders but disadvantage small farmers.

The Protection of New Plant Varieties Act 2004 (PNPV Act 2004) is an intellectual property legislation that specifically regulates farmers' rights and new plant variety in Malaysia. The Act was gazetted on 1 July 2004 and came into operation since 20 October 2008. This Act is supplemented by the Protection of New Plant Varieties regulations 2008[28]. The Malaysian PNPV Act 2004 was based on India's Protection of Plant Varieties and Farmers' Rights Act 2001 (PPVFR 2001) and slightly departs from 
UPOV 1991[29]. This Malaysian statue contains specific provisions for protecting the rights of the small farmers and traditional farming communities although its main objective is to protect plant breeders' rights over their newly created varieties[30].

As for India, the Indian government has passed India's Protection of Plant Varieties and Farmers' Rights Act in 2001 (PPVFR 2001). The Indian statue also contains specific provisions which integrate the rights of breeders of plant varieties and address the concerns of farming communities of India in the agricultural industry[31]. Through this piece of legislation India has to a certain extent successfully created a sui generis system which takes into account the agricultural biotechnology processes and their impacts on farmers and seed industries of India. The Organisation of African Union (now known as African Union) Model Law (OAU Model Law) was promulgated in response towards protection of Africa's common biological diversity through a sui generis system. The OAU Model Law protects not only new plant varieties but include as well protection of the rights of diverse communities of Africa and their indigenous knowledge as well as the rights of farmers and fishermen together with their technologies, innovations and practises. The OAU Model Law was adopted by African Union (AU) Head of States in June 1998 , and serves as a framework for member states of AU to craft out specific national legislation consistent with their own political and social economic development.

In the light of the recent events in the international intellectual property scenarios in the agricultural sector, this study lays out three questions in order to investigate the relationship between the small farmers/smallholders rights in the agricultural industry, in relation to PGRFA and intellectual property protection for plant varieties.

- Does the PNPV Act 2004 provide protection as articulated under Article 9 of the FAO Treaty or merely exemptions for farmers' communities' rights over PGRFA?

- Is the protection accorded under the Malaysian PNPV Act 2004 for farmers comparable to those accorded to farmers' communities in India under India's PPVFR 2001 and OAU Model Law ?

- Is the existing legislation in Malaysia contributes to the small farmers'/smallholders' welfare or do they hold back their rights to their traditional agricultural ways?

\section{Observation}

In order to answer the above questions, it is imperative to examine on how the Malaysian PNPV Act 2004 protects the rights of small farmers and traditional communities as one of the method of ensuring the continuous source of livelihood for the farming community and towards crop genetic biodiversity conservation.

In Malaysia, protection over PGRFA under the IP regime is still new in the sense that there is a limited number of in depth researches has been done on it. Kanniah, Manap et al, Sabrina Hashim \& D.Len and Ida Madiha A.G Azmi[32], all commented on the Plant Variety Protection Act 2004 of Malaysia in a very general manner and discusses the legislation from a formal point of view. Their writings are more on the commentary of the specific provisions of the Act rather than of its impact towards protection or recognition of small farmers/small holders in the agricultural sector. There is also currently very limited legal literature that compares in depth the extent of IP protection on PGRFA and farmers' rights, on a comparative basis between Malaysia India and OAU Model Law.

A suggestion to resolve the highlighted issues is to study the practices and laws in India as it similar common law jurisdiction and its development of a sui generis legislation of IP protection over PGRFA which takes into account the needs of its farming and agricultural communities. The fact that the Indian PPVFR 2001 is referred to in the process of promulgating Malaysian PNPV Act 2004, makes India as an ideal country to be compared with. Whereas OAU Model Law is a legislation which not only emphasis on the rights of farmers but further elaborates on the rights of different traditional communities over their traditional knowledge and genetic resources.

\section{REFERENCES}

Nadine Saad, Louise Sperling and Jacqueline A. Ashby, 2009, Farmers and Plant Genetic Resources, Biotechnology: Agricultural Biotechnology, Vol. VIII, Encyclopaedia of Life Support Systems (EOLSS), EOLSS Publishers, Oxford, UK, p 291-292.

M S Swaminathan, 1998, Farmers' Rights and Plant Genetic Resources, Biotechnology and Development Monitor, No. 36, p 6.

Martin Girsberger, 1999, Biodiversity and the Concept of Farmers' Rights in International Law: Factual Background and Legal Analysis, Peter Lang AG, European Academic Publisher, p 102.

Food and Agriculture Organisation, The State of the World's Plant Genetic Resources for Food and Agriculture (1998) 33 (hereinafter State of the World's PGRFA), Chapter 1

AT Mushita, 1992, Seed Improvement and Farmers' Rights in Zimbabwe, in Biotechnology and Farmers' Rights: Opportunities and Threats for Small-scale Farmers in Developing Countries, (eds.) Hans Brouwer, Erim M Stokhof \& Joske FG Bunders, VU University Press, Amsterdam, pp 35 
Miguel A. Alteiri, 2009, Agroecology, Small Farms and Food Sovereignty, Monthly Review, Vol. 61, Issue 3, p.103-104.

Claudio Chiarrolla, FAO International Treaty on Plant Genetic Resources and Farmers' Rights, at http://www.ias.unu.edu/sub_page.aspx? catID=35\&dd1 ID=1 $91(6 / 3 / 2012)$

Craig Borowiak, 2004, Farmers' Rights: Intellectual Property Regimes and the Struggle over Seeds, Politics and Society, Vol. 32, p 514

Craig Borowiak, 2004, Farmers' Rights: Intellectual Property Regimes and the Struggle over Seeds, Politics and Society, Vol. 32, p 513.

Chidi Oguamanam, 2006, Intellectual Property Rights in Plant Genetic Resources: Farmers' Rights and Food Security of Indigenous and Local Communities, Drake Journal of Agricultural law, Volume 11, p 274-277.

Sussette Biber-Klemm and Thomas Cottier (eds.), 2006, Rights to Plant Genetic Resources and Traditional Knowledge: Basic Issues and Perspectives, CABI, pp xxivxxv.

Southern and Eastern African Trade Information and Negotiations Institute (SEATINI), 'Uganda's Plant Variety Protection Bill, 2010: Where are the Smaller Farmer's and Community Rights?' (2010) $1<$ http://www.seatiniuganda.org/downloads/Reports/ ugandas\%20plant\%20variety\%20bill.pdf $>, 3$.

As a specialised agency established in 1945 under the auspices of United Nations, FAO is an intergovernmental organisation which is linked to the UN Economic and Social Council. FAO efforts are all aimed towards achieving food security for all, ensuring people regular access to enough and quality to sustain healthy lives. Among its main objectives are increasing levels of nutrition, improving agricultural productivity and conditions of rural populations and thus contributing towards expansion of world economy. See www.fao.org for details on the organisation.

The FAO Treaty is discussed more detail in Chapter 4 of the thesis.

See paragraph 4 of the Preamble (Appendix 1).

This particular declaration was adopted in 1996, together with the World Food Summit Plan of Action during the
World Food Summit held in Rome. The Summit was an event discussing on issues of food security and on measures to tackle the problem of food insecurity globally. Both of these documents form the initial framework for ongoing efforts to eliminate hunger. The World Summit Plan also recognises the need for farmers and farming communities to have easy access to PGRFA as a measure to combat food insecurity under paragraph (f) of Objective 2.1 of its Plan of Action. See Mark Gibson, 2012, The Feeding of Nations: Redefining Food Security for the 21st century, CRC Press Inc., p 284-285.

Article 3 of the FAO Treaty states that the Treaty "relates to plant genetic resources for food and agriculture."

Gerald Moore and Witold Tymowski, 2005, Explanatory Guide to International Treaty on Plant Genetic Resources for Food and Agriculture, International Union for Conservation of Nature and natural Resources (IUCN), Gland, Switzerland and Cambridge, UK, p 1-2.

Article 9.1: "The Contracting parties recognise the enormous contribution that the local and indigenous communities and farmers of all regions of the world, particularly those in the centres of origin and crop diversity, have made and will continue to make for the conservation and development of plant genetic resources which constitute the basis of food and agriculture production throughout the world."

Southern and Eastern African Trade Information and Negotiations Institute (SEATINI), 'Uganda's Plant Variety Protection Bill, 2010: Where are the Smaller Farmer's and Community Rights?' (2010) <http://www.seatiniuganda.org/downloads/Reports/ugandas $\% 20$ plant\%20variety\%20bill.pdf $>, 3$.

Regine Andersen, 2008, Governing Agro biodiversity: Plant Genetics and Developing Countries, Ashgate Publishing Limited, England, p 95.

Article 9.2 of the FAO Treaty.

Regine Andersen, 2008, Governing Agro biodiversity: Plant Genetics and Developing Countries, Ashgate Publishing Limited, England, p 112-114.

Craig Borowiak, 2004, Farmers' Rights: Intellectual Property Regimes and the Struggle over Seeds, Politics and Society, Vol. 32, p 511 
See for example discussions on paddy farmers, a section of the small farmers community in Malaysia by Zaim Fahmi, Bahaman Abu Samah \& Haslinda Abdullah, 2013, Paddy Industry and Paddy Farmers Well-being: A Success Recipe for Agriculture Industry in Malaysia, Asian Social Science; Vol. 9, No. 3; pp 177-181; Md. Mahmudul Alam, Chamhuri Siwar, Md. Wahid Murad, Rafiqul Islam Molla, Mohd Ekhwan Toriman, 2010, Socioeconomic Profile Of Farmer In Malaysia: Study On Integrated Agricultural Development Area In North-West Selangor, Agricultural Economics and Rural Development, New Series, Year VII, no. 2, p. 249265 .

See under List of Multilateral Treaty entered by Malaysia under the official website of Ministry of Foreign Affairs, Malaysia at www.kln.gov.my.

See Article 9 of the FAO Treaty.

See the Department of Agriculture, Malaysia website information on the plant variety protection system in Malaysia at http://pvpbkkt.doa.gov.my (31 Jan 2013).

UPOV is the acronyms for the Convention's French name - L' Union internationale pour la Protection des Obtentions Vegetales and was entered into force in 1968. International Convention for the Protection of New Varieties of Plants (UPOV Convention) is an international treaty which provides recognition to the rights of commercial breeders of new plant varieties through plant breeders' rights (PBR). It was constituted in 1961 and at its earliest stage the member state was mostly European countries. It was subsequently revised in 1972 and 1978 and with further revision in 1991; the Convention strengthened the rights of commercial breeders as against the farmers. The rights of farmers were diluted and made optional pursuant to these amendments. See Christopher Sexton, 'A Review of the Enforcement of Plant Breeder's Rights' (2008) (75), Intellectual Property Forum, p 2.

See Preamble to the Act which states: " An Act to provide for the protection of the rights of breeders of new plant varieties, and the recognition and protection of contribution made by farmers, local communities and indigenous people towards the creation of new plant varieties;..."

P Brahmi, S Saxena and BS Dhillon, 'The Protection of Plant Varieties and Farmers' Rights Act of India' (2004) 86(3) Current Science 392. The Indian Patent Act 1970 excludes agricultural and horticultural methods of production from patent.
J A Ekpere, 2001, The OAU's Model Law - The Protection of the Rights of Local Communities, Farmers and Breeders and for the Regulation of Access to Biological Resources: An Explanatory Booklet, Organization of African Unity.

See Refer R. Kanniah, 2005, Plant Variety protection in Indonesia, Malaysia, the Philippines and Thailand, Journal of World Intellectual Property, Volume: 8; , N. A. Manap, Z. A. Zainol, S. M. Hussein, N. M. Sidik and R. Shafiee, 2007, The Intellectual Property Rights for New Plant Varieties: A Malaysian Perspectives, BILETA Conference 2007, S. M. Hashim and D. Len, 2005, Plant Intellectual Property: A Look at the Protection of New Plant Varieties Act 2004 (Act 634), Malayan Law Journal (MLJ) ,I. M. b. A. G. Azmi, 2004, The Protection of Plant Varieties in Malaysia, Journal of World Intellectual Property, Volume: 7. All these articles provides only a general overview on the existing IP protections over PGR and does not delve into the discussions on farmers and traditional communities rights. 